\title{
ISLAM, ETNISITAS, DAN POLITIK IDENTITAS: Kasus Sunda
}

\author{
Abdul Syukur \\ Fakultas Ushuluddin UIN Sunan Gunung Djati \\ Jl. Raya Cipadung, No. 105, Cibiru, Bandung, 10614 \\ e-mail: abdul_syukur05@yahoo.com
}

\begin{abstract}
Abstrak: Dalam kerangka pemikiran struktural-fungsional masyarakat digambarkan terdiri dari sejumlah struktur yang memiliki fungsi sendiri sehingga menciptakan equilibrium yang harmonis berdasarkan solidaritas sosial yang dibangun oleh nilai dan norma kolektif. Begitu pula masyarakat Sunda terikat oleh nilai budaya bersama yang diwariskan secara turun temurun. Mayoritas orang Sunda beragama Islam, yang mengindikasikan bahwa budaya masyarakat Sunda bersumber dari, atau sesuai dengan, nilai-nilai ajaran Islam, sehingga melahirkan ungkapan bahwa "Sunda adalah Islam." Kenyataan adanya kelompok yang bukan Muslim tetapi mereka masih bagian dari dan mengaku sebagai orang Sunda menunjukkan keterbatasan model pemikiran di atas. Tulisan ini berupaya membahas wacana "Sunda adalah Islam" dengan menggunakan teori identitas sebagai suatu kategori etnik, problematika dan implikasi yang mungkin ditimbulkannya.
\end{abstract}

\begin{abstract}
Islam, Ethnicity and the Politics of Identity: The Sundanese Case. In the framework of structural-functionalist thought, society is depicted to constitute from structures belonging to separate function that create harmonious equilibrium based on social solidarity founded in collective norms and values. Accordingly, the Sundanese community is also bound by their communal cultural values received through their ancestors. The majority of the Sundanese are Muslims which indicate that their social culture originates from, or in line with, the values of Islamic teachings that led to the expression that "Sunda is Islam". The fact that there exist groups of Sundanese who are non-Muslim but they still belong to and convicted to be Sundanese show the shortcomings of the above-mentioned model of thought. This writing is an attempt to discuss "Sunadanese Is Islam" discourse by utilizing identity theory as an ethnic category, problems and implication that minght be drawn there in.
\end{abstract}

Kata Kunci: antropologi, Sunda, Islam, etnisitas, politik identitas 
MIQOT Vol. XXXV No. 2 Juli-Desember 2011

\section{Pendahuluan}

Sebagian orang memahami bahwa masyarakat merupakan kumpulan individu dan mereka membentuk masyarakat melalui ikatan kontrak sosial. Emile Durkheim (18581917) ${ }^{1}$ justru memandang bahwa tidak ada individu yang lahir dari belah batu dan terasing dari masyarakat. Sebaliknya, setiap individu lahir dari sebuah keluarga dan besar di tengahtengah masyarakat. Konsekuensi metodologis dari pandangan Durkheim ini ialah bahwa setiap penelitian sosial harus meletakkan perhatiannya pertama-tama pada masyarakat, yaitu adanya fakta-fakta sosial yang mengikatnya dan bersifat memaksa kepada setiap individu tersebut. Sebagai contoh, individu yang lahir dari orang-orang Sunda akan diperkenalkan dan dipaksa untuk berbicara bahasa Sunda, berperilaku menggunakan standar norma dan etika masyarakat Sunda, dan jika kebetulan orang tuanya beragama Islam, maka ia akan diperkenalkan tentang agama Islam dan diajari melaksanakan ajaran-ajaran agama Islam sebagaimana yang dipeluk oleh kedua orang tuanya dan masyarakat di sekitarnya.

Dalam konteks agama Islam, apa yang dikatakan Durkheim di atas mengingatkan kepada sabda Nabi Muhammad SAW. yang mengatakan bahwa "Setiap anak lahir dalam keadaan fitrah, maka kedua orangtuanyalah yang akan menjadikannya Yahudi, Nasrani, atau Majusi." Sekalipun Rasulullah menyatakan hal tersebut dalam konteks agama, tetapi boleh jadi yang dimaksud beliau mencakup wilayah yang lebih luas, yaitu aspek-aspek budaya lainnya seperti bahasa dan norma.

Mengapa masyarakat terintegrasi? Terhadap pertanyaan ini, Durkheim menjelaskan bahwa suatu masyarakat terintegrasi karena pada setiap masyarakat terdapat fakta-fakta sosial yang berfungsi mengikat setiap individu yang menjadi anggota ke dalam masyarakat tersebut. Fakta sosial ini dapat berupa aturan-aturan, norma-norma, dan tradisi yang secara kolektif berlaku atau dilaksanakan oleh masyarakat yang bersangkutan (conscience collective). Selanjutnya, fakta-fakta sosial ini menjadi semacam pegangan hidup bersama, dan karena menjadi pegangan bersama maka ia memiliki sifat memaksa. Artinya, setiap individu harus berperilaku sesuai dengan aturan dan norma-norma yang terdapat pada masyarakatnya. Karena kalau tidak demikian, maka ia akan menghadapi sanksi atau ancaman hukuman dari masyarakat di sekitarnya. Dengan demikian, tidak ada pilihan lain bagi individu yang ingin selamat dan memperoleh rasa aman kecuali tetap bergabung dengan masyarakat dan mengikuti aturan-aturan dan norma-norma yang ada yang dipaksakan oleh masyarakat tersebut.

Herbert Spencer (1820-1903) ${ }^{2}$ mengidentikkan masyarakat dengan suatu organisme. Sebagai sebuah organisme, masyarakat terdiri dari bagian-bagian di mana setiap bagian

${ }^{1}$ Daniel L. Pals, Seven Theories of Religion, terj. Ali Noer Zaman, Cet. 1 (Yogyakarta: Qalam, 2001), h. 158.

${ }^{2}$ Paul Buhanan and Mark Glazer (ed.), High Points in Anthropology (New York: Alfred A. Knopf, 1988), h. 7. 
memiliki fungsi tersendiri. Apabila setiap bagian yang masing-masing membangun struktur sosial berfungsi dengan baik, maka secara otomatis struktur-struktur itu akan membentuk bangunan masyarakat yang utuh. Sebaliknya, apabila ada bagian atau struktur sosial yang tidak berfungsi dengan baik, maka ia akan menjadi beban atau bahkan penyakit bagi masyarakat yang bersangkutan, sehingga akibat yang paling buruk yang mungkin terjadi adalah bagian tersebut harus diamputasi. Pandangan Spencer dan Durkheim ini kemudian melahirkan sebuah teori, yang dalam Sosiologi dan Antropologi dikenal dengan teori StrukturalFungsionalisme.

Terdapat sebuah ungkapan di kalangan masyarakat Sunda yang menyatakan bahwa "Sunda adalah Islam," sebuah ungkapan yang, kurang lebih maknanya sama, juga dapat ditemukan di kalangan orang-orang Melayu, ${ }^{3}$ Minang, dan juga Aceh. Akan tetapi, identifikasi demikian ternyata bukan tanpa masalah, karena identifikasi tersebut berimplikasi, paling tidak, pada kesimpulan sederhana tapi menyesatkan bahwa orang Sunda pasti beragama Islam. Di lain pihak, kenyataan memperlihatkan bahwa tidak semua orang Sunda beragama Islam.

Identitas adalah konstruksi sosial, yaitu bahwa identitas dikonstruksi oleh masyarakat dan dalam proses ini berkaitan erat dengan pemilahan siapa aku dan siapa kamu, siapa kita (we) dan siapa mereka (them). ${ }^{4}$ Dengan kata lain, pengkonstruksian identitas ini menyangkut proses inklusi-eksklusi. Dalam konteks ini, identifikasi "Sunda adalah Islam" dapat berarti bahwa orang Sunda harus beragama Islam dan seperti dikemukakan Ekadjati, ${ }^{5}$ akan menjadi aneh apabila ada orang Sunda yang tidak beragama Islam. Pertanyaannya kemudian adalah bagaimana dengan orang-orang Sunda yang beragama selain agama Islam, apakah dengan begitu berarti mereka sudah tidak menjadi orang Sunda lagi? Pertanyaan selanjutnya adalah adakah makna di balik pernyataan atau ungkapan tersebut, apa yang melatarbelakanginya, dan tujuan apa kira-kira yang hendak dicapainya.

Dengan latar belakang masalah di atas, maka tulisan ini akan membahas pertamatama tentang arti dari pernyataan "Sunda adalah Islam," alasan-alasan yang menyertainya, dan upaya-upaya politik mempertahankannya. Selanjutnya, akan dibahas tentang masalah Sunda itu sendiri sebagai suatu kategori "etnik," problematika dan implikasi yang mungkin ditimbulkannya. Konsekuensi dari identifikasi semacam itu sangat luar biasa, karena secara logika berarti bahwa orang Sunda harus beragama Islam dan bahwa orang Sunda yang tidak memeluk agama Islam bukanlah orang Sunda, dan ini berarti adanya eksekusi terhadap

${ }^{3}$ Jacob Sumardjo, "Islam dan Sunda dalam Mitos: Pandangan Manusia Sunda Masa Kini Hubungannya dengan Islam," dalam dalam Moeflich Hasbullah (ed.), Studi Sejarah Islam Sunda (Bandung: Fakultas Adab dan Humaniora, Universitas Islam Negeri Sunan Gunung Djati, 2010), h. 122.

${ }^{4}$ Fiona Bowie, The Anthropology of Religion (Oxford: Blackwell Publishers, 2001), h. 71.

${ }^{5}$ Edi S. Ekadjati, "Islam: Agama Pilihan Utama dan Abadi Orang Sunda," dalam Moeflich Hasbullah (ed.), Studi Sejarah Islam Sunda (Bandung: Fakultas Adab dan Humaniora, Universitas Islam Negri Sunan Gunung Djati, 2010), h. 81. 
orang-orang Sunda lainnya. Terakhir, dalam kaitannya dengan aspek-aspek sejarah, geografis, serta budaya tersebut kemudian akan dibahas relevansi pernyataan "Sunda adalah Islam" dalam konteks hubungan antar etnik di Indonesia.

\section{Seperti Gula dengan Manisnya}

Istilah lain yang memiliki pengertian yang sama dengan ungkapan "Sunda adalah Islam" adalah perumpamaan yang populer dalam bahasa Sunda bahwa orang Sunda dan agama Islam itu ibarat gula jeung peueutna, yaitu seperti gula dengan rasa manisnya. Ungkapan ini memberikan pengertian bahwa hubungan antara orang-orang Sunda dengan Islam sangatlah erat, sehingga bahkan karena eratnya, keduanya tidak dapat dipisahkan lagi, karena meskipun tidak setiap yang manis itu gula, tetapi tidak ada gula yang rasanya tidak manis.

Terkait dengan ungkapan "Sunda adalah Islam" di atas, Kahmad, dalam makalahnya yang berjudul "Agama Islam dan Budaya Sunda,"6 mengatakan bahwa antara kebudayaan Sunda dengan ajaran agama Islam memang sulit dipisahkan. Hal ini karena, menurut Kahmad, orang-orang Sunda dapat menerima dengan mudah ajaran-ajaran agama Islam. Penerimaan Islam dengan mudah oleh orang-orang Sunda ini selain dimungkinkan oleh adanya cara dakwah Islam yang telah disampaikan melalui pendidikan ketimbang penaklukan, juga karena karakter agama Islam yang tidak jauh berbeda dengan karakter budaya Sunda, yaitu bersifat sederhana, dan Islam yang masuk ke tataran Sunda telah dibungkus oleh kebudayaan Timur yang tidak asing lagi bagi orang-orang Sunda. Karena itu, proses Islamisasi masyarakat Sunda dapat berjalan dengan mulus dan lancar. Dengan kata lain, meskipun agama Islam berasal dari luar, tetapi karena unsur-unsurnya terdapat kesesuaian, maka Islam dapat diterima dengan kedua belah tangan terbuka oleh orang-orang Sunda, sehingga terjadilah proses asimilasi dan akulturasi antara berbagai budaya yang membungkus Islam dengan nilai-nilai budaya lokal Sunda. Umpamanya, sekalipun secara tradisi masyarakat Sunda masih melaksanakan upacara-upacara adat seperti babarit (upacara kehamilan) empat bulan atau tujuh bulan, memperingati kematian tiga hari (tiluna), tujuh hari (tujuhna), empat puluh hari (matang puluh), seratus hari (natus), dan seterusnya, tapi upacara-upacara tradisional tersebut telah dipadukan dengan doa-doa yang bersumber pada ajaran agama Islam. Karena telah terjadi perpaduan antara ajaran Islam dan nilai-nilai budaya Sunda itulah, maka kini antara keduanya sulit untuk dipisahkan, ibarat gula jeung peueutna (gula dengan manisnya).

Alwasilah, ${ }^{7}$ membuat rincian tentang nilai-nilai yang terkandung dalam kebudayaan

${ }^{6}$ Disajikan pada International Roundtable Discussion on Islamic Thought and Sundanese Values yang diselenggarakan oleh CESRAS (Centre for the Study of Religion and Society) UIN Sunan Gunung Djati, Bandung, kerjasama dengan The Catholic University of America, The Islamic College, dan MIZAN tanggal 9 Januari 2009.

${ }^{7}$ Chaedar Alwasilah, "Islamic Thoughts and Sundanese Values," makalah disampaikan pada acara International Roundtable Discussion on Islamic Thought and Sundanese Values, 
Sunda yang ditemukan dalam peribahasa, idiom-idiom, ungkapan-ungkapan yang populer di kalangan masyarakat Sunda, yaitu:

1. Manusia harus memiliki tujuan yang mulia dalam kehidupannya.

2. Manusia adalah bagian kecil dari alam semesta, karena itu harus melestarikan alam dan jangan merusaknya supaya mendapat keuntungan daripadanya.

3. Manusia harus menyadari dan belajar dari alam, masyarakat, dan Tuhan.

4. Manusia memerlukan guru yang mengajari mereka tentang yang baik dan yang buruk.

5. Manusia harus belajar dari, terutama, orang tua dan kemudian dari orang lain.

6. Manusia harus menjaga dan menghormati nilai-nilai yang ada yang masih relevan sebagai petunjuk.

7. Manusia harus mencontoh orang tua dan leluhur dalam melakukan tradisi, sehingga orang tua harus memberikan contoh sebagai model perilaku yang baik.

8. Manusia harus memperhatikan kearifan-kearifan tradisional dalam menghadapi masa yang akan datang.

9. Manusia harus ingat pada kehidupan setelah mati.

10. Manusia harus saling menghormati, melaksanakan etika, bicara dan berperilaku sopan dan ramah.

11. Manusia harus melindungi yang lemah secara ekonomi, berpihak pada yang benar, dan bertindak tegas.

12. Manusia dianugrahi kekuatan oleh Tuhan, sehingga mereka harus tunduk kepada-Nya.

13. Manusia harus memiliki sifat-sifat ikhlas, sabar, cerdas, jujur, waspada, dan mental bertanggung jawab.

14. Manusia harus memperlihatkan sikap siger tengah (tidak bersikap keterlaluan).

15. Manusia harus memiliki sifat-sifat ideal seperti hurip (penuh semangat), waras (sehat fisik), cageur (sehat mental), bageur (baik pada sesama), bener (benar), pinter (pintar), ludeung (berani), silih asah (saling mengingatkan), silih asih (saling mencintai), dan silih asuh (saling menjaga).

Menurut Alwasilah, nilai-nilai budaya Sunda sebagaimana yang diungkapkannya di atas ternyata sesuai dan sejalan dengan nilai-nilai ajaran Islam.

Keterkaiatan erat antara agama Islam dengan budaya Sunda ini bahkan mengantarkan Ekadjati ${ }^{8}$ kepada kesimpulan yang dinyatakan secara mencolok dalam judul tulisannya yaitu "Islam: Agama Pilihan Utama dan Abadi Orang Sunda." Kesimpulan demikian diperoleh Ekadjati berdasarkan alasan adanya fakta bahwa sementara orang-orang Sunda dapat

diselenggarakan oleh CESRAS (Centre for the Study of Religion and Society) UIN Sunan Gunung Djati, Bandung, kerjasama dengan The Catholic University of America, The Islamic College, dan MIZAN, 9 Januari 2009.

${ }^{8}$ Ekadjati, Islam: Agama Pilihan Utama, h. 81. 
dengan mudah menerima agama Islam, tetapi ternyata tidak demikian halnya terhadap agama-agama yang lain. Hal ini dibuktikan ketika kolonial Barat memperkenalkan agama Nasrani kepada mereka, tetapi mereka tetap tidak tergoda.

Kesimpulan Ekadjati di atas tampaknya diperkuat oleh bukti adanya laporan yang merupakan hasil analisis para misionaris Belanda, J. Verhoeven, yang membandingkan antara karakter orang-orang Sunda dan orang Jawa, dan P.N. Gijsman. Menurut Verhoeven, orang-orang Jawa dalam keberagamaan memang kurang taat, namun dalam hal bekerja mereka termasuk orang-orang yang rajin dan ulet. Sebaliknya, orang-orang Sunda termasuk orang-orang yang malas bekerja, namun dalam hal keberagamaan mereka adalah orangorang yang taat. Karena ketaatannya kepada agama Islam itulah, maka orang-orang Sunda sangat antusias untuk melaksanakan ibadah haji dan masyarakat Sunda termasuk salah satu kelompok yang mengirim rombongan jemaah haji yang terbanyak. Gijsman, bahkan, mengatakan bahwa Islam bagi masyarakat Sunda sudah bukan lagi hanya sekedar bungkus, tapi sudah menjadi jiwa dalam tata perilaku dan aktivitas kehidupan sehari-hari. Karena itu, para misionaris Belanda tersebut sampai kepada kesimpulan bahwa Kristenisasi di kalangan masyarakat Sunda sangat sulit, kalau bukan tidak mungkin. ${ }^{9}$

Contoh lain adalah Gerakan Darul Islam (DI) yang dipimpin Sekar Marijan Kartosuwiryo, menjadikan basis gerakannya di tatar Sunda, yaitu di Garut. Kartosuwiryo adalah orang Jawa yang menikah dengan gadis dari Kecamatan Malangbong, Garut. Ia kemudian berhasil menyebarkan pengaruhnya hampir di seluruh wilayah Priangan. Keberhasilan gerakan Katosuwiryo erat kaitannya dengan fakta bahwa masyarakat Sunda, khususnya Priangan, adalah orang-orang yang memiliki semangat keagamaan yang kuat yang menginginkan tegaknya syariat Islam. Salah satu indikatornya adalah bahwa pada Pemilu tahun 1955, dua partai yang berlandaskan agama Islam, yaitu Partai Masyumi dan Nahdlatul Ulama (NU), memperoleh suara yang sangat signifikan di Priangan dibandingkan dengan partaipartai lainnya. Amin Mudzakkir dalam tulisannya berjudul Islam Priangan: Pergulatan Identitas dan Politik Kekuasaan, dengan mengutip Herbert Feith (1999: 97), mengemukakan tabel perbandingan perolehan suara antara lima partai besar di Priangan sebagai berikut: ${ }^{10}$

\begin{tabular}{c|cc|c|c}
\hline Partai & Suara Parlemen & Konstituante & Perbedaan \\
\hline PNI & 1.541 .927 & 1.586 .507 & +44.580 \\
\hline Masyumi & 1.844 .442 & 1.761 .406 & -83.036 \\
\hline NU & 673.466 & 692.755 & +19.289 \\
\hline PKI & 755.643 & 827.858 & +72.215 \\
\hline PSII & 393.174 & 384.790 & -8.384 \\
\hline
\end{tabular}

${ }^{9}$ De Nederlandse Zendings-Vereniging in West Java 1858-1963, doc. 97, h. 208 dan doc. 48, P.N. Gijsman, h. 144-5.

${ }^{10} \mathrm{http}: / /$ penelitianku.wordpress.com/2009/03/04/islam-priangan-pergulatan-identitasdan-politik-kekuasaan. 
Pada masa sekarang, khususnya masa reformasi dan sejalan dengan kebijakan otonomi daerah (Otda), ekspresi keberagamaan masyarakat Sunda yang kuat itu di beberapa daerah dinyatakan dalam bentuk dibuatnya Peraturan Daerah (Perda). Dua daerah yang sangat bersemangat mengekspresikan agama Islam dalam bentuk penegakkan syariat Islam lewat Perda tersebut, menurut Mudzakkir, adalah Kabupaten Cianjur dan Kabupaten Tasikmalaya. Di Cianjur, Wasidi Swastomo, sejak proses pengajuan calon Bupati, merupakan satusatunya calon yang secara terbuka menjanjikan akan memberlakukan "syariat Islam." Ketika akhirnya ia terpilih menjadi Bupati Cianjur untuk periode 2001-2006, maka pada 1 Muharram 1422/26 Maret 2001, ia pun memenuhi janjinya dengan mendeklarasikan "Gerbang Marhamah" (Gerakan Pembangunan Masyarakat Berakhlakul Karimah). Kemudian, melalui SK. Bupati Cianjur No. 34/2001 Wasidi membentuk Lembaga Pengkajian dan Pengembangan Islam (LPPI) yang beranggotakan tokoh-tokoh kiai dan aktivis politik Muslim dan bertugas menyusun teknis pelaksanaan pemberlakuan "syariat Islam" di Cianjur.

Langkah selanjutnya, Wasidi mengeluarkan SK No. 451/277/ Asda-1/2001 yang berisi petunjuk tentang apa yang menjadi materi Gerbang Marhamah. Materi-materi itu mencakup (1) Membiasakan/membudayakan salat berjamaah terutama pada saat jam kerja (zuhur berjamaah); (2) Membiasakan/membudayakan mengeluarkan zakat, infak, dan shadaqah setiap rizqi/pendapatan yang diterima; (3) Meningkatkan kegiatan pengajian di unit kerja, majelis taklim, dan tempat lainnya; dan (4) Menciptakan lingkungan yang Islami dan kepada aparatur pemerintah hendaknya memberi contoh keteladanan (uswah al-hasanah).

Bupati Cianjur berikutnya, Tjetjep Muhtar Sholeh, memberi dukungan terhadap pembahasan Rancangan Peraturan Daerah (Raperda) Gerbang Marhamah yang diajukan oleh Bupati Wasidi sebelumnya. Maka, Raperda Gerbang Marhamah disetujui menjadi Perda No.3/2006 pada tanggal 20 Juli 2006. Menyusul penetapan Perda No.3/2006 tentang Gerbang Marhamah, Bupati pun mengeluarkan dua peraturan untuk mengimplementasikan Perda tersebut. Pertama, Peraturan Bupati Cianjur No.15/2006 tentang Pakaian Dinas Harian Pegawai di lingkungan Pemerintah Kabupaten Cianjur. Kedua, Instruksi Bupati Cianjur No.2/2007 tentang pemasangan papan visi dan misi Kabupaten Cianjur serta penyelenggaraan pengajian/tadarus al-Qur'an.

Di Kabupaten Tasikmalaya, sesuai dengan PP No. 108/2000 yang mengharuskan setiap Pemerintah Daerah membuat rencana strategis (renstra) bagi acuan pelaksanaan pembangunan, kalangan politisi dari partai-partai Islam mengajukan ide untuk memasukan nuansa "syariat Islam" ke dalam renstra. Renstra Kabupaten Tasikmalaya 2001-2005 itu akhirnya disepakati dan dituangkan dalam Perda No. 13/2001. Akan tetapi, terdapat bagian yang kontroversial dalam Perda itu yang kemudian menjadi bahan perseteruan, yaitu adanya pencantuman visi Kabupaten Tasikmalaya "yang religius/Islami sebagai pusat pertumbuhan di Priangan Timur serta mampu menempatkan diri menjadi kabupaten yang maju di Jawa Barat pada tahun 2010". Sekalipun begitu, Bupati Tasikmalaya tetap mengeluarkan Surat Edaran No. 451/SE/Sos/2001 tentang upaya peningkatan kualitas keimanan dan ketakwaan sebagai 
bentuk realisasi dari visi Kabupaten Tasikmalaya yang religius/Islami tersebut. Dalam perkembangannya, karena banyaknya kritik terhadap visi kabupaten sebagaimana tertuang dalam Perda No. 13/2001, dua tahun kemudian visi renstra direvisi dengan Perda No. 13/ 2003 di mana visi Kabupaten Tasikmalaya mengalami sedikit perubahan, namun masih tetap mempertahankan nuansa ke-Islam-an, menjadi "Tasikmalaya yang religius/Islami sebagai kabupaten yang maju dan sejahtera serta kompetitif dalam bidang agribisnis di Jawa Barat tahun 2010". Dikaitkan dengan visi Kabupaten Tasikmalaya yang tercantum dalam renstra, yaitu sebagai kabupaten yang "religius/Islami," maka peraturan-peraturan tersebut dipandang sebagai "Perda Syariat." Tetapi dengan peraturan-peraturan semacam itu, maka kemudian dapat dipertanyakan bahwa apakah dengan demikian Kabupaten Cianjur dan Kabupaten Tasikmalaya mencerminkan keterkaitan antara ajaran agama Islam dengan nilai-nilai budaya Sunda? Atau justru sebaliknya, hal itu mencerminkan bahwa terdapat kesenjangan antara orang-orang Sunda di Kabupaten Cianjur dan Kabupaten Tasikmalaya dengan ajaran Islam, sehingga mereka harus disatukan (atau: dipaksa bersatu!) lewat perdaperda tersebut.

\section{Mana yang Sunda?}

Di antara etnik-etnik yang ada di Indonesia, etnik Sunda merupakan etnik nomor dua terbesar setelah etnik Jawa. Menurut Wikipedia, jumlah etnik Sunda adalah 31 juta dan mayoritas orang Sunda beragama Islam. Menurut Sensus Penduduk tahun 2000 jumlah pemeluk agama Islam di Jawa Barat sebanyak 37.606.317 yang, seperti dikatakan Kahmad, membentuk 98\% dari seluruh penduduk Jawa Barat yang beretnik Sunda. Persoalannya sekarang adalah apakah dengan begitu dapat dikatakan bahwa Jawa Barat merepresentasikan etnik Sunda dan bahwa "Sunda adalah Islam"? Karena, Wikipedia tidak hanya menempatkan etnik Sunda secara geografis di daerah Jawa Barat, tetapi juga di Banten dan Jakarta. Persoalan selanjutnya adalah manakah dan siapakah yang dimaksud dengan "Sunda"?

Sebelum memisahkan diri dan menjadi provinsi sendiri tahun 2000, Banten memang merupakan bagian dari provinsi Jawa Barat, sehingga dapat dimengerti pernyataan bahwa mayoritas etnik Sunda terdapat di Jawa Barat. Sekalipun telah terpisah dari provinsi Jawa Barat, tetapi karena di Banten sendiri terdapat komunitas yang mengaku dirinya sebagai orang Sunda, maka dapat dimengerti kalau orang Sunda tidak hanya terdapat di Jawa Barat, tetapi juga di Banten. Masyarakat Baduy di Desa Kanekes Kecamatan Leuwidamar, Kabupaten Lebak di Banten, misalnya, adalah komunitas warisan dari Kerajaan Sunda, yaitu Pakuan Pajajaran, yang mengasingkan diri bersamaan dengan terjadinya proses Islamisasi di tanah Sunda. ${ }^{11}$ Desa Kanekes terdiri dari 3 kampung utama yang terletak di

${ }^{11}$ Dadan Wildan, "Perjumpaan Islam dengan Tradisi Sunda," dalam Moeflich Hasbullah (ed.), Studi Sejarah Islam Sunda (Bandung: Fakultas Adab dan Humaniora, Universitas Islam Negri Sunan Gunung Djati, 2010), h. 86-87. Bandingkan dalam Harian Pikiran Rakyat (26 Maret 2003). 
daerah Baduy Dalam (Kajeroan), yaitu Cikeusik, Cikertawana, dan Cibeo, dan 28 kampung lainnya serta 8 kampung babakan (pemekaran) yang tersebar di wilayah Baduy Luar (Panamping, Pasisian). ${ }^{12}$

Tidak dapat dipungkiri bahwa pada umumnya orang-orang Sunda bertempat tinggal di Pulau Jawa bagian barat, tetapi mengidentikan Jawa Barat (termasuk Banten) dengan Sunda tidaklah tepat. Karena ternyata pada umumnya penduduk di pantai utara daerah Jawa Barat maupun Banten berasal dari dan menggunakan bahasa Jawa dalam berkomunikasi. Sebaliknya, dapat ditemukan komunitas Sunda di bagian barat provinsi Jawa Tengah, seperti di Kabupaten Cilacap dan Kabupaten Brebes. Selain itu, Jakarta, yang dikatakan dalam Wikipedia juga sebagai daerah yang secara dominan etnik Sunda, beserta kota-kota besar lainnya di Jawa Barat dan Banten sekarang cenderung dihuni oleh penduduk campuran dari berbagai etnik.

Identifikasi Sunda dengan bahasa pun bukan tanpa masalah. Hasbullah pernah mengungkapkan keluhannya tentang adanya dampak dari kehidupan multi-etnik di kotakota besar seperti di atas terhadap penggunaan bahasa Sunda di tanah Sunda. Menurutnya, terdapat kecenderungan di mana orang-orang Sunda di kota-kota besar, khususnya di Jawa Barat, lebih suka menggunakan bahasa Indonesia dalam berkomunikasi daripada menggunakan bahasa Sunda. Disebutkan bahwa dengan alasan gengsi dan takut dianggap tidak modern, maka keluarga orang-orang Sunda pun kini tidak suka lagi menggunakan bahasa Sunda dalam percakapan dengan anak-anak mereka, sehingga kemudian anakanak mereka pun canggung berbahasa Sunda dan lebih memilih menggunakan bahasa Indonesia dalam berkomunikasi dengan teman-temannya. Selanjutnya, dikatakan bahwa mereka lebih merasa akrab memanggil "papih-mamih," "papah-mamah," "ayah-ibu," kepada kepada orang tuanya dari pada memanggil mereka dengan sebutan "abah-ambu," "emaapa" atau "indung-bapa."13

Kemajuan teknologi transportasi dan komunikasi selain menyebabkan globalisasi yang menjadikan ruang menjadi sempit dan waktu menjadi pendek juga menyebabkan terjadinya deteritorialisasi. Seperti dikemukakan di atas, mengidentifikasi Jawa Barat dan Banten dengan Sunda selain bermasalah karena secara geografis Jawa Barat dan Banten tidak hanya dihuni oleh orang-orang Sunda, juga banyak orang-orang Sunda sekarang tidak lagi terkungkung oleh batas-batas geografis. Dapat juga ditemukan orang-orang Sunda di Jawa bagian Tengah maupun Timur, di Sumatra, Kalimantan, bahkan di Papua dan di luar negri. Seperti kebanyakan etnik lainnya, mereka pun rata-rata mengaku beragama Islam.

${ }^{12}$ A. Suhandi Sam, et al., Tata Kehidupan Masyarakat Baduy di Propinsi Jawa Barat (Jakarta: Departemen Pendidikan dan Kebudayaan Proyek Inventarisasi dan Dokumentasi Kebudayaan Daerah, 1986), h. 10.

${ }^{13}$ Moeflich Hasbullah, "Islam, Sunda dan Tantangan Modernitas" dalam Moeflich Hasbullah (ed.), Studi Sejarah Islam Sunda (Bandung: Fakultas Adab dan Humaniora, Universitas Islam Negri Sunan Gunung Djati, 2010), h. 127. 
Tetapi apakah karena pengakuan mereka beragama Islam lantas dapat secara sederhana dikatakan bahwa "Sunda adalah Islam"?

Bagaimana pun angka 98\% yang menyatakan bahwa penduduk Jawa Barat beragama Islam, seperti yang dikatakan Kahmad, ${ }^{14}$ atau, sebagaimana dikatakan Ekadjati bahwa 95\% orang Sunda menganut agama Islam, ${ }^{15}$ tetap menyisakan ruang kemungkinan bagi adanya orang-orang Sunda yang memeluk agama di luar Islam. Baik Kahmad maupun Ekadjati, begitu juga penulis dan peneliti tentang Sunda lainnya, mengakui bahwa di samping Islam, yang dipeluk secara mayoritas, juga terdapat agama-agama lain yang menjadi anutan orang-orang Sunda. Sunda Wiwitan, yaitu agama karuhun (nenek moyang) masyarakat Sunda, misalnya, masih dipertahankan oleh sebagian masyarakat Sunda. Begitu pun sebagian masyarakat Sunda di Cideres (Majalengka) dan Cikembar (Sukabumi) menganut agama Katolik dan Protestan. Bahkan, penganut Kebatinan atau Penghayat Kepercayaan pun dapat ditemukan dalam masyarakat Sunda Cigugur (Kuningan) dan Ciparay (Bandung).

Fakta-fakta di atas memperlihatkan betapa problematis dalam mengidentifikasi yang namanya "Sunda." Secara geografis, Jawa Barat dan Banten tidak lagi dihuni oleh manusia Sunda, dan orang-orang Sunda sudah tidak lagi dibatasi oleh sekat-sekat geografis. Begitu pula dalam perspektif bahasa. Sekalipun di daerah-daerah yang relatif homogen orangorang Sunda masih menggunakan bahasa Sunda dalam berkomunikasi, tetapi di daerahdaerah urban sudah banyak yang tidak bisa berbahasa Sunda lagi. Pelajaran bahasa Sunda di sekolah-sekolah kurang diminati, apalagi oleh anak-anak yang dilahirkan dari proses perkawinan etnik campuran (anomali). Lantas, bagaimanakah dengan identifikasi bahwa "Sunda adalah Islam"?

\section{Sunda: Antara Pajajaran, Majapahit, Banten dan Cirebon}

Sebagaimana dikemukakan di atas bahwa pengkonstruksian identitas berkaitan erat dengan proses inklusi-eksklusi. Ini berarti pula bahwa identitas merupakan aspek relasional, yaitu terjadi dalam hubungan dan interaksi sosial di mana suatu kelompok sosial akan mengidentifikasi dirinya dalam hubungannya dengan kelompok atau golongan lain (others), sehingga masing-masing saling mengidentifikasi. Proses pengidentifikasian ini terjadi dalam situasi dan kondisi tertentu. Dengan kata lain, pengkonstruksian identitas dilakukan secara kontekstual sehingga apabila situasi dan kondisi berubah, maka otomatis konstruksi identitas pun akan mengalami perubahan. ${ }^{16}$ Sekalipun hubungan dan interaksi sosial meng-

${ }^{14}$ Dadang Kahmad, "Agama Islam dan Budaya Sunda," makalah disampaikan pada acara International Roundtable Discussion on Islamic Thought and Sundanese Values, 9 Januari 2009; Moeflich Hasbullah (ed.), Studi Sejarah Islam Sunda (Bandung: Fakultas Adab dan Humaniora, Universitas Islam Negri Sunan Gunung Djati, 2010).

${ }^{15}$ Ekadjati, Islam: Agama Pilihan Utama, h. 81.

${ }^{16}$ Thomas Hylland Eriksen, Ethnicity and Nationalism: Anthropological Perspectives (London: Pluto Press, 1995), h. 62. 
andaikan keseimbangan, tetapi kenyataan sering kali memperlihatkan adanya ketidaksetaraan. Dalam hal ini, maka hubungan antar kelompok sosial kerap ditandai oleh adanya persaingan, kontestasi, resistensi, dan bahkan konflik.

Secara historis, Pajajaran adalah kerajaan Sunda terakhir dengan rajanya yang terkenal yaitu Prabu Siliwangi. Namun cikal bakal kerajaan ini adalah Kerajaan Sunda di Pakuan (Bogor) dan Kerajaan Galuh di Kawali (Ciamis) yang dipersatukan di bawah kekuasaan Rakeyan Jamri, pewaris tahta Kerajaan Galuh, yang menikah dengan Tejakencana, Putri Mahkota Kerajaan Sunda, dan berkuasa antara tahun 723-732 dengan ibukotanya di Kawali (Ciamis). Di bawah kekuasaan Sri Baduga Maharaja yang berkuasa antara tahun 1482-1521, ibukota kerajaan dipindahkan ke Pakuan (Bogor). Menurut prasasti Batutulis, Sri Baduga Maharaja, yang kemudian dikenal sebagai Prabu Siliwangi, mendirikan parit sebagai benteng pertahanan mengelilingi ibukota kerajaan. Karena Pakuan, ibukota Kerajaan Sunda, ini berada sejajar dengan dua buah sungai, yaitu Ciliwung dan Cisadane, maka nama kerajaan pun berubah menjadi Pakuan Pajajaran. Karena itu, kerajaan ini sering disebut Kerajaan Pakuan atau, lebih dikenal lagi, Kerajaan Pajajaran.

Selain memindahkan ibukota dari Kawali ke Pakuan dan membangun benteng pertahanan yang kuat, Prabu Siliwangi juga berhasil mengonsolidasikan kekuasaan dan keamanan. Di bawah kekuasaannya pula masyarakat Sunda dapat merasakan kesejahteraan dan menikmati kemakmuran, sehingga zaman Siliwangi kerap dianggap sebagai zaman keemasan Kerajaan Sunda Pajajaran. Karena alasan itu pulalah, Prabu Siliwangi mendapat tempat istimewa di hati sebagian masyarakat Sunda.

Akan tetapi, sejarah Siliwangi dan Kerajaan Pajajaran bukanlah awal dan akhir cerita. Sebelumnya telah bertahta raja-raja lain dengan riwayatnya sendiri. Prabu Maharaja Lingga Buana naik tahta di kerajaan Sunda Galuh di Kawali (Ciamis) pada tahun 1340. Meskipun menurut Pustaka Rajyarajya i Bhumi Nusantara, Parwa II Sarga 3, terdapat hubungan darah antara Kerajaan Sunda Galuh dan Kerajaan Majapahit, sehingga raja-raja Majapahit enggan untuk menaklukan kerajaan Sunda, tetapi ambisi Patih Gajahmada dari Kerajaan Majapahit untuk menyatukan kedua kerajaan di Pulau Jawa tersebut telah membawa orang Sunda kepada perasaan malu dan terhina serta memandang dengan sebelah mata terhadap orang-orang Jawa. Ketika Raja Hayamwuruk (berkuasa 1350-1389) dari Majapahit menyatakan keinginannya untuk mempersunting Dyah Pitaloka alias Citraresmi, putri Maharaja Lingga Buana dari Kerajaan Sunda Galuh, kesempatan ini dimanfaatkan dengan sebaikbaiknya oleh Patih Gajahmada. Dengan tipu dayanya Maharaja Lingga Buana beserta keluarga kerajaan tidak menanti kedatangan Hayamwuruk yang akan mempersunting putrinya, melainkan mereka berangkat mengantarkan Sang Putri ke Majapahit. Akan tetapi, sebelum sampai di ibukota kerajaan Majapahit, rombongan Kerajaan Sunda Galuh tersebut beristirahat dan mendirikan perkemahan, yaitu di daerah Bubat, sambil menunggu waktu pernikahan dan jemputan dari Majapahit.

Rombongan dari Majapahit memang datang, tetapi bukan untuk menjemput Sang 
Putri dan keluarganya dari Kerajaan Sunda Galuh. Pada kesempatan itu, malahan Gajahmada menyampaikan tuntutan kepada Kerajaan Sunda Galuh untuk takluk kepada Majapahit, dan alih-alih Dyah Pitaloka akan dijadikan permaisuri ia dianggap sebagai upeti atas takluknya Kerajaan Sunda Galuh tersebut. Merasa dipecundangi, maka keluarga Kerajaan Sunda Galuh tersebut menolak tuntutan Gajahmada, dan ketika Gajahmada dan pasukannya melakukan penyerangan, maka keluarga Kerajaan Sunda Galuh pun, meski pada akhirnya kalah dan luluh lantak, mengadakan perlawanan. ${ }^{17}$ Dyah Pitaloka sendiri, demi mempertahankan harga diri dan kehormatan keluarga, melakukan tindakan bunuh diri. Itulah sebabnya, maka nama Gajahmada, yang dalam buku-buku sejarah dikatakan sebagai pemersatu kepulauan Nusantara dengan Sumpah Palapanya yang terkenal, dimasukan ke dalam daftar hitam dalam memori masyarakat Sunda, sehingga tidak ada yang namanya Jl. Gajahmada di wilayah orang-orang Sunda.

Kerajaan Pajajaran bukanlah satu-satunya kerajaan Sunda yang pernah berdiri di tanah Sunda. Ia hanyalah satu mata rantai dari rangkaian panjang sejarah kerajaan-kerajaan yang pernah ada yang bermuara pada Kerajaan Tarumanegara yang didirikan oleh Purnawarman pada pertengahan abad $5 \mathrm{M}$. dan kerajaan ini masih berdiri hingga abad $7 \mathrm{M} .{ }^{18}$ Pada tahun 670, Tarusbawa, raja ke-13 yang naik tahta tahun 669 menggantikan mertuanya, mengganti nama Tarumanegara menjadi Kerajaan Sunda. Setelah itu kerajaan ini pun mengalami pasang surut. Terpecah menjadi Kerajaan Sunda di Pakuan (Bogor) dan Galuh di Kawali (Ciamis); bersatu kembali di bawah kekuasaan Rakeyan Jamri yang dikenal sebagai prabu Harisdarma atau Sanjaya; berganti-ganti ibukota kerajaan dari Galuh ke Pakuan atau sebaliknya. Mengalami masa kejayaan dan keemasan di bawah Sri Baduga Maharaja alias Prabu Siliwangi yang bertahta dari 1482-1521 dan menjadi raja pertama dari Kerajaan Pakuan Pajajaran. Kemudian mengalami kemunduran dan akhirnya menderita kehancuran sejak masa Prabu Surawisesa Jayaperkosa alias Ratu Sang Hyang sampai Raja Mulya alias Prabu Surya Kencana, yang dalam Carita Parahyangan dikenal sebagai Nusa Mulya, yang bertahta dari 1567-1579.

Patut dikemukakan di sini bahwa sebagai pewaris dan penerus tradisi Tarumanegara, Kerajaan Pajajaran dan Prabu Siliwangi sendiri pada dasarnya adalah kerajaan dan raja Hindu di mana Purnawarman menganggap dirinya sebagai titisan Dewa Wisnu. Atau, paling tidak perpaduan antara kepercayaan lokal, Sunda Wiwitan, dengan agama Hindu dan Buddha. Kalau Kerajaan Sunda Galuh ditaklukan oleh Majapahit yang sama-sama kerajaan Hindu, maka Pajajaran mengalami kekalahan oleh rangkaian serangan dari Kesultanan Banten dan Cirebon yang Islam. Kesultanan Banten dan Cirebon adalah perpanjangan tangan dari Kerajaan Islam Demak yang kemudian menjadi dua pusat kekuasaan Islam di Jawa Barat. Karena itu, mengiringi kekalahan Kerajaan Pajajaran oleh Kesultanan Banten

\footnotetext{
${ }^{17}$ George Coedes, Asia Tenggara Masa Hindu-Buddha, terj. Winarsih Partaningrat Arifin (Jakarta: Kepustakaan Populer Gramedia, 2010), h. 320.

${ }^{18}$ Ibid., h. 88.
} 
maka proses Islamisasi di wilayah Pajajaran pun semakin intens, sehingga akhirnya rakyat Pajajaran menerima dan menjadikan Islam sebagai agama anutan mereka. Meskipun rakyat Pajajaran telah menganut agama Islam, akan tetapi kenangan tentang Prabu Siliwangi dan Kerajaan Pajajaran sebagai raja dan kerajaan Sunda tampaknya sulit dihapuskan dari memori kolektif orang-orang Sunda. Karena itu, menarik dikemukakan di sini apa yang dikatakan oleh Wibisana tentang ambivalensi orang-orang Sunda, bahwa sesungguhnya "junjungan orang Sunda sampai saat ini sebenarnya ada dua, yakni Nabi Muhammad (bila mereka menempatkan diri sebagai umat Islam) dan Prabu Siliwangi (bila mereka sedang menyadari kesundaannya)."19

Menurut hikayat Carita Parahyangan, ketika kerajaan Pajajaran mengalami kemunduran dan kemudian hancur oleh kekuatan Banten yang Islam, ibukota kerajaan sudah tidak lagi bertempat di Pakuan, melainkan di Pulasari, Pandeglang atau di Keduhejo, Kecamatan Menes. Rakyat kerajaan Pajajaran yang tidak mau menerima agama Islam yang didakwahkan oleh kesultanan Banten inilah yang di kemudian hari menjadi bagian dari orang-orang Sunda dan dikenal sebagai orang-orang Baduy, dan mereka tetap mempertahankan kepercayaan lama dan tradisi leluhur Pajajaran yang kemudian disebut mereka sebagai Agama Sunda Wiwitan.

Wildan, mengutip Djatisunda (1992:2-3), mengatakan bahwa orang-orang Baduy menyebut orang-orang Sunda yang beragama Islam sebagai "Sunda Eslam," yang berarti bahwa sekalipun berbeda agama tetapi secara etnik mereka menganggapnya tidak ada perbedaan. Pertanyaannya sekarang adalah apakah memang benar demikian adanya? Bowie mengatakan bahwa batas-batas identitas bersifat contested, yaitu bahwa penarikan batas-batas dilakukan dalam hubungan kontestasi antara berbagai kelompok sosial. Selain ini, bahwa orang-orang Baduy menyebut orang-orang Sunda Priangan sebagai Urang Wetan (Orang Timur). Ini berarti bahwa boleh jadi mereka menganggap orang-orang Sunda Priangan, seperti mereka, sebagai sama-sama orang Sunda. Tetapi istilah "Urang Wetan" bukanlah ungkapan biasa yang tanpa makna. Istilah "Urang Wetan" merupakan stereotype yang dibuat orang Sunda Baduy yang dikenakan terhadap Sunda Priangan untuk membedakan bahwa secara kultural mereka berbeda. "Urang Wetan" berarti orang-orang Sunda yang berada timur (mencakup Bandung, Garut, Ciamis, Tasikmalaya, Sumedang, Cianjur, Sukabumi, dan Bogor) di mana mereka telah mengalami dominasi Majapahit-Hindu dan Mataram-Islam dan, karena itu, budaya mereka telah dipengaruhi kebudayaan Jawa. Kalau orang Sunda Baduy masih mempertahankan cara bercocok tanam padi huma (berladang), maka orang Sunda Priangan dengan cara bersawah; kalau orang Sunda Baduy dalam pergaulan sosial masih memperlihatkan sikap egaliter, maka orang Sunda Priangan lebih bersifat feodal.

\footnotetext{
${ }^{19}$ Wahyu Wibisana, "Pengaruh Islam terhadap Budaya Sunda (Catatan Perbandingan dan Pencerahan," dalam Moeflich Hasbullah (ed.), Studi Sejarah Islam Sunda (Bandung: Fakultas Adab dan Humaniora, Universitas Islam Negri Sunan Gunung Djati, 2010), h. 95.
} 
Adanya proses Islamisasi tatar Sunda yang dilakukan oleh kesultanan Banten dan kesultanan Cirebon sebagai perpanjangan tangan Demak dan Mataram Islam yang berakibat pada terjadinya "Jawanisasi" terhadap kebudayaan Sunda diakui oleh Kahmad. Ia mengemukakan contoh pengaruh kebudayaan Jawa terhadap kebudayaan Sunda tersebut, selain dalam hal bertani dan pergaulan sosial di atas, juga ditunjukkan oleh adanya undakusuk (tatakrama) dalam bahasa Sunda yang mengindikasikan feodalisme dalam sistem sosial masyarakat Sunda. Undak-usuk dalam bahasa Sunda merupakan pengaruh dari tatakrama bahasa kromo-inggil (ditujukan kepada priyayi) dan ngoko (ditujukan kepada masyarakat biasa) sehingga dalam bahasa Sunda pun dikenal bahasa Sunda lemes (halus) yang ditujukan kepada para menak (priyayi) dan bahasa Sunda kasar yang ditujukan kepada masyarakat biasa.

\section{Berharap pada Provinsi Pasundan}

Masa reformasi adalah masa euforia kebebasan. Dengan alasan demokratisasi maka rakyat bebas mengemukakan pendapat dan menyatakan kehendaknya. Hal ini didukung oleh kebijakan pemerintah sendiri dengan mengeluarkan kebijakan Otonomi Daerah (Otda) untuk mengurangi beban kerja pemerintah pusat dan membaginya dengan pemerintah daerah. Sejalan dengan kebijakan Otda dan kebebasan menyatakan kehendak, maka inisiatif pemekaran wilayah atau daerah pun bermunculan, baik di tingkat provinsi, kabupaten/ kota, bahkan sampai ke tingkat desa.

Di Jawa Barat, salah satu daerah yang berusaha memisahkan diri dan membentuk provinsi sendiri terpisah dari Jawa Barat adalah Banten, yang sebelumnya dikenal sebagai Keresidenan Banten yang mencakup 3 kabupaten (Serang, Pandeglang dan Lebak) dan satu kota Cilegon. Dengan alasan menuntut realisasi janji pemerintah masa Presiden Soekarno dan kurangnya perhatian dari pemerintah provinsi Jawa Barat, maka akhirnya pada tahun 2000 Banten pun berdiri menjadi provinsi sendiri.

Wacana pemekaran dan pembentukan provinsi dan kabupaten baru menjadi fenomena umum pasca Reformasi, dan pemekaran wilayah Jawa Barat dengan pembentukan provinsi baru yaitu provinsi Banten merupakan proses pemekaran yang terjadi pada masa-masa awal sekali. Pemisahan Banten dari provinsi Jawa Barat sangat melukai perasaan orangorang Sunda, khususnya di Priangan, bukan hanya karena pemerintah provinsi Jawa Barat telah berusaha memberikan perhatian yang lebih dengan melakukan pembangunan untuk kemajuan Banten, melainkan lebih disebabkan oleh faktor sentimen etnisitas di mana Banten dan Jawa Barat sama-sama daerah mayoritas etnik Sunda. Dalam konteks hubungannya dengan etnik Jawa perpisahan Banten dengan Jawa Barat menjadi pukulan tersendiri dan menorehkan rasa malu berikutnya pada sejarah orang-orang Sunda. Memang di kalangan etnik Jawa pun terdapat desakan di beberapa daerah untuk membentuk provinsi sendiri terpisah dari provinsi-provinsi Jawa Tengah dan Jawa Timur yang sudah ada, seperti provinsi Banyumas, Daerah Istimewa Surakarta, provinsi Muria Raya, provinsi Jawa Utara, dan 
provinsi Madura. Tetapi hal itu hanya menjadi wacana yang sampai sekarang tidak pernah terjadi.

Setelah Banten memisahkan diri, sebagian orang Sunda berusaha memunculkan lagi isu ke-Sunda-an. Dengan mengemukakan alasan bahwa provinsi Jawa Barat sekarang tidak lagi berada di bagian barat Pulau Jawa dan mengenang kembali nama "Pasundan" pada masa Republik Indonesia Serikat (RIS), mereka pun mengajukan untuk mengganti nama provinsi Jawa Barat menjadi provinsi Pasundan. "Pasundan" berarti hal-hal yang berkaitan dengan Sunda dan, karena itu, dengan nama "Pasundan" diharapkan memberikan kesan khusus terhadap orang lain yang mendengarnya. Seperti nama "Priangan" atau "Parahyangan" yang menyiratkan tentang keindahan alam tatar Sunda sebagai tempat bersemayamnya para dewa (hyang) yang hidup di alam surgawi.

"Pasundan" memang pernah menjadi nama dari sebuah negara bagian dari Republik Indonesia Serikat (RIS), yaitu "Negara Pasundan." "Negara Pasundan" adalah bentukan Belanda pada tanggal 24 April 1948 yang secara historis dianggap sebagai upaya Belanda untuk memecah belah Indonesia. Karena itu, ketika "Negara Pasundan" didirikan, masyarakat Sunda terpecah. Sementara orang-orang Sunda Priangan menerima, tetapi orang-orang Sunda Banten menolaknya. Ketika Presiden Soekarno mengembalikan bentuk negara federasi kepada Negara Kesatuan Republik Indonesia, Banten mendukung kebijakan politik tersebut. Itulah sebabnya Presiden Soekarno merasa "berutang budi" dan berjanji kepada Banten untuk menjadikannya sebuah provinsi. Dalam pandangan orang Sunda Banten, keinginan orang-orang Sunda Priangan mengambil kembali nama "Pasundan" sebagai nama provinsi Jawa Barat dengan merujuk kepada sejarah "Negara Pasundan" justru menyiratkan sejarah kelam Sunda itu sendiri.

Provinsi Pasundan memang kemudian tidak terwujud. Tetapi tidak teralisasinya provinsi Pasundan ternyata bukan karena bercermin pada sejarah masa lalu, melainkan karena adanya resistensi dari Cirebon. Keresidenan Cirebon yang mencakup Ciayumajakuning (Kota dan Kabupaten Cirebon, Kabupaten Indaramayu, Kabupaten Majalengka, dan Kabupaten Kuningan) menolak adanya usaha penggantian nama provinsi Jawa Barat menjadi provinsi Pasundan, dan seandainya usaha tersebut terus dilakukan maka mereka mengancam akan memisahkan diri dan membentuk provinsi sendiri. Sekalipun telah membentuk presidium dan pembentukan provinsi Cirebon telah dideklarasikan, namun kemudian provinsi itu ternyata tidak terbentuk, begitu pula provinsi Pasundan.

Masyarakat di Wilayah Cirebon, khususnya Kota dan Kabupaten Cirebon serta Kabupaten Indramayu, kebanyakan adalah orang-orang Jawa. Karena itu, sekalipun Cirebon terletak di Jawa Barat yang didominasi oleh orang-orang Sunda, tetapi bagi orang-orang Cirebon nama "Pasundan" dianggap terlalu eksklusif. Selain itu, sebagai salah satu pusat penyebaran agama Islam di Jawa Barat Cirebon memiliki kebanggaan tersendiri dan ini menjadi bagian dari alat bagi orang-orang Jawa Cirebon untuk bernegosiasi dalam kancah wacana pembentukan provinsi Pasundan. 
Di lain pihak, gagalnya pembentukan provinsi Cirebon ternyata bukan karena gagalnya penggantian nama provinsi Pasundan, sehingga orang-orang Cirebon merasa masih terakomodasi dalam provinsi Jawa Barat. Sebagaimana diberitakan dalam Berita Cirebon, gagalnya pembentukan provinsi Cirebon ternyata lebih disebabkan adanya penolakan untuk bergabung dari Kabupaten Kuningan dan Kabupaten Majalengka. ${ }^{20}$ Meski alasan yang dikemukakan Yudi Budyana, Ketua DPRD Kuningan, bahwa penolakan Kabupaten Kuningan bukan karena perbedaan kultur, melainkan terlalu dini, emosional, dan cenderung mengandung muatan politik dari pihak-pihak yang kecewa, tetapi tampaknya nuansa perbedaan etnik dan budaya tetap berperan. Mayoritas penduduk Kabupaten Kuningan dan Kabupaten Majalengka adalah etnik Sunda. Sementara itu, masyarakat di Kota dan Kabupaten Cirebon dan Kabupaten Indramayu didominasi oleh etnik Jawa. Orang-orang Jawa di Wilayah Cirebon sendiri sebenarnya berada di persimpangan jalan, karena meski mereka Jawa tetapi kultur dan bahasa Jawa mereka ternyata sangat berbeda dengan kultur dan bahasa Jawa daerah lainnya. ${ }^{21}$ Mereka tampaknya menyadari hal itu. Karena itu, mereka lebih suka mengidentifikasi dirinya sebagai "orang Cirebon" dari pada sebagai orang Jawa, sehingga dalam Sensus Penduduk Tahun 2000 terdapat kategori kelompok etnik "Cirebon."22

\section{Nasib Orang yang Tidak Putus Dirundung Malang}

Apabila, seperti dikemukakan Wildan di atas, orang-orang Sunda Baduy yang mempertahankan Agama Sunda Wiwitan masih menganggap orang-orang Sunda yang beragama Islam sebagai sama-sama orang Sunda, tetapi mengapa orang-orang Sunda yang beragama Islam mengidentifikasi "Sunda" dengan "Islam"?

Seperti dikemukakan di atas, secara kuantitas etnik Sunda adalah etnik nomor dua terbesar. Sekalipun demikian, jarang orang-orang Sunda yang muncul dalam percaturan sosial dan politik Indonesia. Dalam kaitannya dengan masalah ini menarik untuk disimak apa yang dikatakan Hasbullah dalam tulisannya di atas bahwa sejarah Sunda adalah sejarah kekalahan:

Secara historis, sejarah Sunda -dibandingkan dengan Jawa misalnya- adalah sejarah yang kalah. Kerajaan-kerajaan Sunda seperti Tarumanegara, Galuh, Pajajaran dan Sumedang Larang, adalah kerajaan-kerajaan lokal dan tidak ekspansionis sehingga tidak memiliki supremasi besar seperti luasnya pengaruh dan banyaknya taklukan kerajaan-kerajaan lain. Kerajaan Sunda adalah taklukan kerajaan Majapahit, Mataram

\footnotetext{
${ }^{20}$ Berita Cirebon, 10 Maret 2009 dan 19 Agustus 2009.

${ }^{21}$ Seorang teman dari Solo pernah menceritakan pengalamannya ketika ia bertandang ke Cirebon. Ia mengatakan bahwa ia merasa asing dan ketika berkomunikasi, ia tidak mengerti sama sekali bahasa Jawa yang diucapkan oleh orang-orang Cirebon.

${ }^{22}$ Leo Suryadinata, et al., Indonesia's Population: Ethnicity and Religion in a Changing Political Landscape (Singapore: Institute of Southeast Asian Studies, 2003), h. 7.
} 
dan Demak. Identitas asli kebudayaan Sunda pun karam dalam hegemoni kebudayaan yang lebih besar seperti Jawa, Islam dan Barat. ${ }^{23}$

Dari pernyataan Hasbullah di atas maka dapat dikatakan bahwa, kecuali orangorang Baduy yang dianggap sebagai pewaris dan penerus budaya Sunda Pajajaran dengan agama Sunda Wiwitannya, orang-orang Sunda pada umumnya mengalami kehilangan identitas setelah mengalami penaklukan yang terus menerus oleh kerajaan-kerajaan Jawa sejak sebelum zaman Majapahit, Banten dan Cirebon. Penaklukan oleh Demak dan Mataram Islam memang membawa dampak pada diperkenalkannya agama Islam pada masyarakat Sunda sehingga terjadi proses Islamisasi Sunda. Akan tetapi, seperti dikatakan Kahmad, Islamisasi Sunda ini ternyata tidak lepas dari proses Jawanisasi sehingga secara kultural budaya Sunda pun mengalami "kontaminasi."

Kekalahan secara politik dan budaya masa silam ini berakibat pula pada kalahnya orang-orang Sunda masa kini dalam konteks percaturan politik-kekuasaan nasional. Pada masa kolonial Bandung pernah menjadi semacam kawah candradimuka bagi orangorang yang aktif dalam bidang politik. Dari sinilah lahir tokoh-tokoh kaliber nasional, bahkan internasional, seperti Soekarno, M. Natsir, dan lain-lain. Ironisnya, Soekarno sendiri adalah orang Jawa, sedangkan M. Natsir berasal dari Sumatra. ${ }^{24}$ Bandung sendiri, bersama-sama dengan Garut, Tasikmalaya, dan Sukabumi, kini hanya melahirkan artis-artis ${ }^{25}$ dan hanya menjadi salah satu pusat seni dan mode.

Setelah Pajajaran tidak dapat diharapkan, diperkenalkannya Islam sepertinya membawa angin segar bagi masyarakat Sunda yang ingin mempertahankan identitasnya. Dalam hal ini, Islam menjadi alternatif untuk membangun kembali budaya Sunda, sehingga Islam menjadi sumber rujukan dalam merajut kembali nilai-nilai budaya Sunda yang telah "terkontaminasi." Dengan dijadikannya Islam sebagai sumber rujukan, maka akan memberikan ciri tersendiri bagi budaya Sunda dan dapat membedakannya dari budaya Jawa yang sarat dengan kepercayaan dan tradisi mistiknya.

Memang Islam masuk ke masyarakat Sunda lewat penaklukan oleh kerajaan-kerajaan Jawa, dan mayoritas masyarakat Jawa menganut agama Islam. Tetapi Islam yang masuk ke Jawa dan diterima oleh masyarakat Jawa mengalami proses Jawanisasi dalam pengertian disaring dan disesuaikan dengan kebudayaan Jawa. Dalam terminologi antropologi, Islam yang masuk ke Jawa lebih bersifat asimilatif di mana Islam mengalami proses adaptasi terhadap kebudayaan Jawa. Orang Jawa lebih bangga dengan budayanya, sehingga para wali yang menyebarkan agama Islam pun harus menyesuaikan diri terhadap alam pemikiran

${ }^{23}$ Hasbullah, "Islam, Sunda dan Tantangan Modernitas," h. 128.

${ }^{24}$ Pada masa kemerdekaan orang-orang Sunda yang pernah naik ke panggung kekuasaan tingkat nasional di antaranya adalah Ali Sadikin, Umar Wirahadikusumah, Ginanjar Kartasasmita, Agum Gumelar, Mochtar Kusumaatmaja, dan Rachmat Witoelar.

${ }^{25}$ Seperti penyanyi dangdut Elvi Sukaesih, Rhoma Irama, Dessy Ratnasari, Nike Ardila, Iwa Kusuma, dan Evie Tamala. 
orang Jawa. Sehingga, sekalipun para wali rata-rata berasal dari kalangan orang Jawa dan orang Jawa yang beragama Islam lebih banyak dibandingkan dengan orang-orang Sunda, tetapi tidak pernah muncul di kalangan masyarakat Jawa ungkapan yang membanggakan bahwa "Jawa adalah Islam". Di kalangan masyarakat Jawa justru lebih terkenal istilah "Kejawen" yang merupakan bentuk tradisi di mana berbagai kepercayaan yang diterima diramu dalam bingkai budaya Jawa. Dengan demikian, identifikasi budaya dan etnik Sunda dengan Islam, maka orang-orang Sunda dapat membedakan dirinya dengan etnik dan budaya Jawa.

\section{Penutup}

Dalam karangka pemikiran Struktural-Fungsional masyarakat digambarkan sebagai terdiri dari sejumlah struktur yang memiliki fungsi sendiri sehingga menciptakan equilibrium yang harmonis. Supaya tercipta masyarakat yang harmonis, maka setiap individu anggota masyarakat diharapkan dan diharuskan menyesuaikan diri terhadap nilai-nilai, normanorma dan aturan yang menjadi pegangan bersama, dan demi terciptanya masyarakat yang seimbang dan harmonis nilai dan norma-norma tersebut tidak hanya harus disosialisasikan melainkan juga harus dipaksakan, karena pelanggaran terhadap norma dan aturan bersama akan merusak ikatan solidaritas sosial. Dari kacamata ini maka perubahan budaya dan perubahan sosial merupakan sesuatu "haram."

Menjaga dan mempertahankan kebudayaan suatu masyarakat tidak lepas dari peranan para elit masyarakat yang bersangkutan. Di tangan para elit inilah suatu tindakan atau perbuatan yang dilakukan anggota masyarakat dinilai sebagai sesuai atau tidak dengan kebudayaan mereka. Sebagai organisme masyarakat mengalami perkembangan. Kontak antara budaya, yang terjadi lewat individu maupun kelompok-kelompok sosial, memungkinkan terjadinya perubahan kebudayaan suatu masyarakat. Tetapi tetap saja di tangan para elit inilah unsur-unsur budaya yang masuk disaring, diolah, ditolak atau ditetapkan untuk menjadi bagian dari kebudayaannya. Dengan kata lain, perubahan diterima selagi tidak membuat struktur sosial yang lebih besar mengalami perubahan radikal. Itulah sebabnya pendekatan Struktural-Fungsional kerap dianggap sebagai pendekatan yang mendukung status quo.

Dalam konteks hubungan antara Islam dan Sunda, pernyataan "Sunda adalah Islam" dapat dikatakan sebagai upaya dari sekelompok elit orang Sunda dalam mengkonstruksi identitas etnik Sunda, yaitu dengan membedakannya dari budaya etnik Jawa, di satu pihak; dan mengidentikkan Sunda dengan Islam, di pihak lain. Sejarah kekalahan etnik Sunda yang terus menerus oleh kekuatan etnik Jawa memberikan pelajaran kepada elit-elit Sunda untuk menarik batas yang tegas dengan mengidentikkan Sunda dengan Islam.

Mereka menyaring, mengolah, menolak dan menegaskan unsur-unsur budaya apa saja yang harus menjadi identitas Sunda. Dengan mengolah, menolak atau membuat penegasan 
terkait kebudayaan Sunda sama artinya dengan mereka mempertahankan statusnya sebagai kalangan elit, sedangkan status sosial kelompok elit pada suatu masyarakat tertentu adalah status istimewa yang berimplikasi pada hak-hak yang juga istimewa. Terkait dengan perilaku para elit Sunda di atas serta implikasinya maka seolah diingatkan oleh Henley dan Jamie Davidson ${ }^{26}$ yang mengatakan bahwa dalam melihat gerakan kebangkitan masyarakat adat dewasa ini harus diperhatikan sejauh mana mereka yang berbicara atas nama komunitas adat mewakili warga komunitasnya, karena bisa jadi gerakan ini hanya menjadi tunggangan politik segelintir orang demi mengejar dan mempertahankan kekuasaan atau kepentingan pribadi. Dengan nada yang sama di sini bisa juga ditanya apakah dalam identifikasi Sunda dengan Islam atau pemberlakuan Perda Syariat di beberapa kabupaten di Jawa Barat merepresentasikan kehendak masyarakat Sunda atau jangan-jangan sekedar tunggangan politik para elit Sunda untuk mempertahankan status quo demi kekuasaan dan kepentingan pribadi belaka.

\section{Pustaka Acuan}

Alwasilah, Chaedar. "Islamic Thoughts and Sundanese Values," makalah disampaikan pada acara International Roundtable Discussion on Islamic Thought and Sundanese Values, 9 Januari 2009.

Bowie, Fiona. The Anthropology of Religion. Oxford, Blackwell Publishers, 2001.

Buhanan, Paul and Mark Glazer (ed.). High Points in Anthropology. New York: Alfred A. Knopf, 1988.

Coedes, George. Asia Tenggara Masa Hindu-Buddha, terj. Winarsih Partaningrat Arifin. Jakarta: Kepustakaan Populer Gramedia, 2010.

End, TH. Van Den (ed.). De Nederlandse Zendings-Vereniging in West Java 1858-1963, Uitgave Van De Raad Voor De Zending der Ned. Herv. Kerk, De Zending Der Gereformeerde Kerken in Nederland En De Gereformeerde Zendingsbond in De Ned. Herv. Kerk, 1991.

Ekadjati, Edi S. "Islam, Agama Pilihan Utama dan Abadi Orang Sunda," dalam Moeflich Hasbullah (ed.), Studi Sejarah Islam Sunda. Bandung: Fakultas Adab dan Humaniora, Universitas Islam Negeri Sunan Gunung Djati, 2010.

Eriksen, Thomas Hylland. Ethnicity and Nationalism: Anthropological Perspectives. London: Pluto Press, 1995.

Hasbullah, Moeflich. "Islam, Sunda dan Tantangan Modernitas," dalam Moeflich Hasbullah (ed.), Studi Sejarah Islam Sunda. Bandung: Fakultas Adab dan Humaniora, Universitas Islam Negeri Sunan Gunung Djati, 2010.

Henley, David dan Jamie Davidson. "Pendahuluan: Konservatisme Radikal-Aneka Pajah

${ }^{26}$ David Henley dan Jamie Davidson, "Pendahuluan: Konservatisme Radikal-Aneka Wajah Politik Adat," dalam David Henley, et al. (peny.), Adat dalam Politik Indonesia, terj. Emilius Ola Kleden dan Nina Dwisasanti (Jakarta: Yayasan Obor, 2010), h. 6. 
Politik Adat," dalam David Henley, et al. (peny.). Adat dalam Politik Indonesia, terj. Emilius Ola Kleden dan Nina Dwisasanti. Jakarta, Yayasan Obor, 2010.

Http://penelitianku.wordpress.com/2009/03/04/islam-priangan-pergulatan-identitasdan-politik-kekuasaan/

Kahmad, Dadang. "Agama Islam dan Budaya Sunda," makalah disampaikan pada acara International Roundtable Discussion on Islamic Thought and Sundanese Values, 9 Januari 2009.

Pals, Daniel L. Seven Theories of Religion, terj. Ali Noer Zaman. Yogyakarta: Qalam, 2001.

Sam, A. Suhandi, et al. Tata Kehidupan Masyarakat Baduy di Propinsi Jawa Barat. Departemen Pendidikan dan Kebudayaan Proyek Inventarisasi dan Dokumentasi Kebudayaan Daerah, 1986.

Sumardjo, Jakob. "Islam dan Sunda dalam Mitos: Pandangan Manusia Sunda Masa Kini Hubungannya dengan Islam," dalam Moeflich Hasbullah (ed.), Studi Sejarah Islam Sunda. Bandung: Fakultas Adab dan Humaniora, Universitas Islam Negeri Sunan Gunung Djati, 2010.

Suryadinata, Leo, et al., Indonesia's Population: Ethnicity and Religion in a Changing Political Landscape. Singapore: Institute of Southeast Asian Studies, 2003.

Wibisana, Wahyu. "Pengaruh Islam terhadap Budaya Sunda (Catatan Perbandingan dan Pencerahan," dalam Moeflich Hasbullah (ed.), Studi Sejarah Islam Sunda. Bandung: Fakultas Adab dan Humaniora, Universitas Islam Negeri Sunan Gunung Djati, 2010.

Wildan, Dadan. "Perjumpaan Islam dengan Tradisi Sunda," dalam Studi Sejarah Islam Sunda, dalam Moeflich Hasbullah (ed.), Studi Sejarah Islam Sunda. Bandung: Fakultas Adab dan Humaniora, Universitas Islam Negeri Sunan Gunung Djati, 2010. 